\title{
Colloquy
}

\section{SECURITY AGAINST THE STATE IN REVOLUTIONARY YEMEN}

\author{
ROSS PORTER \\ University of Exeter \\ (iD) https: / / orcid.org/0000-0002-4772-4247
}

For a sovereign power to label someone or something a "threat," especially a national one, typically means to situate it beyond the realm of normal politics and within a state of exception. In critical security studies, this process by which a state discerns and designates threats is known as securitization (C.A.S.E. Collective 2006). While this framing is broad enough to account for operations of state power in a diverse range of circumstances, it overlooks two related possibilities, both of which are quintessential features of revolutions, and both of which help broaden our understanding of securitization. The first is the possibility that people can willfully excise themselves from so-called normal politics and, in doing so, knowingly become threats. The second is the possibility that securitization is not just something that states do to their subjects but also something that subjects do to states. Both possibilities define a distinctly revolutionary form of securitization.

\section{SECURITIZING A REVOLUTION}

When revolution erupted in Yemen in 2011, as conspicuous as the event was the speed of its condemnation. As hundreds of thousands of people poured into streets across the nation, feeling jubilant and empowered, political analysts spoke 
of a "political crisis," foreign officials expressed "concern," and skeptics warned of impending "chaos." The register and content of these reactions - by academics, policy think tanks, diplomats, and the regime itself — was remarkably consistent. As the new revolutionaries set up encampments in Yemen's three main cities of Sana'a, Taiz, and Aden, political forecasts remained characteristically Hobbesian: without the state to mediate Yemenis in their rights and duties, "terrorism" would spread, "vacuums" would be filled by "illegitimate non-state actors," and tribes would inevitably feud. Meanwhile, President Ali Abdullah Saleh sought to remind everyone of the achievements of his three-decade rule- "security, stability, unity, and constitutional legitimacy" — while also warning, in the same breath, of an innate propensity for violence among Yemenis.

No sooner had the revolution been diagnosed as a political crisis than international mediators arrived in Sana'a calling for a political solution, by which they meant talks. General consensus among this mediating elite held that the popular will, as articulated in the streets ("the people want . . "), urgently needed to be channeled into a formalized space of political deliberation and style of reasoning congenial to the common good. Where, they asked, were the men and women who would be ready to behave in a civil manner around their enemies at the negotiating table and contain the volatility of what Edmund Burke (2003, 2) warned of, in the French Revolution, as the "wild gas" of the "spirit of liberty"? Saleh, too, called on the new revolutionaries to consider the political option, pleading with them, condescendingly, to organize themselves and elect representatives. Meanwhile, state-run news agencies spread word of the unprecedented national threat; Saleh declared a state of emergency and security forces swiftly descended into the encampments.

\section{A Willing Threat}

It is significant that the revolutionaries proceeded into the domain of the exception fully cognizant of the fate that awaited them. They knew that in the moment of announcing themselves as revolutionaries (thuwār), the state and its allies would cast them as "traitors" and "terrorists," threats to national security, beyond the realm of normal politics and subject to extrajudicial procedures. They knew this because they knew the regime, its methods, and what to expect. This willingness to assume the role of threat proves significant because it unsettles the idea that people who are the objects of securitization must inevitably be understood as its subjects and, by extension, on the basis of their insecurity. By contrast, an assertive and conscious willingness to become a threat evinces a certain degree of 
power, sovereignty, and ideology, more reminiscent of the securitizer than the securitized. The revolutionary individual, in this case, is the self-empowered object of state securitization. Such individuals will willfully extricate themselves from the state's political and legal norms and, in doing so, realize a different notion of what it means to be secure - one based, in turn, on a different notion of what it means to be political. I will work back to this point in what follows.

\section{From Existential Threat to Existential Capacity}

Between 2011 and 2013, I conducted fieldwork in a revolutionary encampment in central Sana'a, known as Change Square. Spread across five miles of inner-city streets, this area was home to tens of thousands of people for nearly three years. I use the word home partly because of the camp's permanency: timber-framed structures with breeze-block foundations, sleeping compartments, and electricity supplies powering satellite dishes and televisions; a market, a hospital, wash blocks, restaurants; seminars and training courses; art galleries; a stage; even a defected army brigade. But beyond the physicality of spatial belonging, home evokes an intimacy between revolutionary self and revolutionary world that, in turn, evinces a particular expression of security.

The defining experience of becoming and identifying as a revolutionary individual was one of rupture between two ways of life. Each of these existences evoke, for this same individual, a different dynamic of securitization, one that is incapacitating (as a securitized subject), and another that is liberating (as a securitizer of sorts). Beginning with the former, revolutionary reflections on prerevolutionary life typically amounted to an expression of subjugation to a coercive sovereign entity. By subjugation, I mean not only brute force but also a life marred by constant moral compromise, unrealizable aspirations, tragic choices, and the kind of uncertainty that follows from the arbitrary casting of threats. By contrast, the new revolutionaries appeared strikingly indifferent to the securitizing agenda of the state, despite the latter's intensification of violence following the eruption of revolution. The revolutionaries found it farcical that they were deemed terrorists, traitors, and general proponents of crisis and chaos. In their minds, they were the "the free revolutionaries," with freedom pertaining to an unprecedentedly self-empowered and sovereign relation to the regime. The effect of this new relation would in turn strip the regime of political legitimacy in the eyes of many of its supporters, redistributing it to the revolution. It is in this redistribution of political legitimacy, and indeed possibility, that we may think about revolution as 
a form of securitization in its own right. Let us consider a few expressions of what this rupture looked like in practice.

\section{Outwitting the State}

Few acts were considered as revolutionary as marching unarmed into gunfire during demonstrations. A typical scene unfolded as follows: thousands of protestors leave Change Square and march through the surrounding streets singing, chanting, and carrying portraits of martyrs from previous demonstrations. Then, seeing a military barricade in the distance or finding themselves ambushed at a junction, the crowds would descend into the breach as machine guns rattled to life, arms wide open and shouting, "we're peaceful."

This act became celebrated as the defining symbol of a revolution primarily because it served to reconfigure the relationship between securitizer and securitized. Many of the individuals heading for the barricades had come to the revolution following a lifetime of conflict with the regime - a conflict in which they had felt perpetually provoked into using violence as part of a carefully orchestrated political strategy of divide and rule. They knew that their own use of violence had played into Saleh's hands to instantiate his position, both locally and internationally, as the guardian of national security. Precisely the knowledge that they had been complicit in their own securitization made marching unarmed into gunfire such an immensely appealing, even liberating, act. Heading for the barricades with their "bare chests," as they would say, the revolutionaries now confronted their adversary in a way that both refused to play into its hands and culminated in a distinctly novel sensation of freedom and moral autonomy. The act also exposed, in stark relief, the illegitimacy of the regime's use of violence and a radically contrasting image of political (and moral) legitimacy now forming around the revolution. It is in this sense that we may allude to revolutionary securitization as the process by which agents of a state unexpectedly find themselves without place or future in a radically alterative and expanding demarcation of the political.

\section{Egalitarian Commitments}

Several miles of streets in the heart of a bustling capital city are covered in tents. In each, thirty or more individuals are deep in the throes of argument and debate. They point fingers at their neighbors, accusing one another of adherence to extraneous ideologies and political preferences. People walk from tent to tent throwing bundles of flyers through doorways, advertising the true intentions of their fellow revolutionaries. Accusations circulate about an attempt to forsake the 
will of the people and of a plot to hijack the revolution. Chants against political parties emanate from a crowd near the central stage. A banner hangs across the street: "No to individual rule." In the newspaper Voice of the Revolution, a journalist writes that no one represents the revolution, that no individual can or will speak for the people. An organization is founded to disorganize organizations seeking to organize the revolution.

If marching unarmed into gunfire was about upholding an unprovoked and desecuritized moral and political self in the face of the state, then within Change Square, an ethos of mistrust constituted the primary means of its maintenance. Throughout the camp, suspicions abounded regarding an elusive enemy in the revolutionaries' midst — an individual, party, or group that, at any moment, would surreptitiously impose its will on "the people" and re-engineer state securitization under a new (potentially revolutionary) banner. To avoid this possibility and ensure that power be kept diffuse and distributed, the only individuals universally trusted as leaders at Change Square were those who could satisfactorily demonstrate, typically through spectacles of selflessness and self-sacrifice, the innocence of their will vis-à-vis the will of the people. Hence the exalted status of the martyrs. It appears curious, however, that the revolutionaries situated this seemingly antistate egalitarian logic within their own vision of a (revolutionary) state. In this ideal, the role of the "citizen" is to diffuse the rise of concentrated power, ensuring that power is the people (in an ontological rather than representational sense). The state thus comes to look very un-stately. And yet, in revolutionary theory, it is a state nonetheless - only one premised on the selfless exploits of its proponents and the simultaneous delegitimization of an authoritarian rival.

\section{For a Crisis of Politics}

Considering the importance attached to safeguarding the revolutionary present against the specter of the past, and specifically a past in which state securitization had been dressed in politically neutralizing garb (e.g., "stability"), it seems hardly surprising that calls by international mediators for reconciliation, dialogue, and negotiation ("political solutions") fell on deaf ears. On the first day of the UN-brokered National Dialogue Conference in 2013, crowds left Change Square carrying pictures of martyrs with the slogan, "Only this list represents us in the Dialogue." Others from the camp ("youth" who had acquired a certain amount of trust) tentatively participated in proceedings, testing their suspicions, only to encounter individuals vying for supremacy and pushing their minoritizing visions of a future state. In the following years, intrarevolutionary mistrust would mutate 
into the war now raging in Yemen. If there is any continuity between the early revolutionary days of Change Square and the current period, it is the suspicion we find toward seemingly amicable invitations to politics and the securitizing agendas they conceal. It is in this vein that we may think about political crisis not just as a diagnostic for the absence of security but also as the direct result of people taking security into their own hands.

\section{CONCLUSION}

Anthropologists can productively contribute to conversations about securitization by bringing the concept into conversation with a diverse range of circumstances and, in doing so, gauging the extent to which the concept can be extended or pluralized. One such conversation thinks about security from below-security "subverted from its original meaning and captured from the state," (El Dardiry and Hermez 2020, 199) as the editors of this colloquy put it. If anthropologists are to take up this challenge, however, they must first redress their preoccupation with the victims of state securitization with a focus on non-state securitizers. To allow for this redress, they must entertain the notion that people who are the intended objects of state securitization are not, necessarily, best understood as its insecure subjects.

Thinking about how people take security into their own hands can lead us in a number of directions. One route will consider how people (willfully or not) do the security work of the state. Darryl Li's (2020) piece highlights the importance of ethnography for humanizing agents of state securitization and, by extension, catalyzing a nascent anthropology of the "enemy." Another considers how people securitize themselves and others on behalf of the state, or do so to make up for the failure of the state. We see the latter expression in Kali Rubaii's (2020) discussion, where she illustrates the ethical work that goes into sustaining human life in times of extreme suffering and risk. Another direction, which I have taken up here, examines how security is deployed against the state from a position of relative autonomy.

The Yemeni revolution could be considered a security event punctuating a life of state-induced insecurity. Revolutionary securitization marks a momentary escape from what Diana Allan (2020) describes as a life marred by perpetual insecurity, where insecurity is not merely a blip but an enduring state of subjection to the relentless "dehumanizing objectifications of neoliberal statecraft." The eventfulness of security, in this case, is constituted by a willed excision from the political norms of the state and the simultaneous embodiment of a rival sovereign 
formation. The effect of this excision and embodiment in the Yemeni revolution was to momentarily render inert the securitizing machinations of an authoritarian state through the cultivation of a more virtuous and liberating "state" of one's own. We find subtle echoes here of what Martin Holbraad and Morten Axel Pedersen (2012) refer to, in the Cuban case, as "revolutionary securitization," defined as the virtuous ontological fusion between oneself and one's legitimate political forms. At Change Square, it was specifically the work that went into defending the sovereignty of one's own, legitimate, political sphere that defined a revolutionary process of securitization. Yet in its subversion from its original meaning, revolution constitutes a form of security that remains largely invisible to the analyst, or politician, for whom the eclipse of the state (in its narrow definition) spells the absence of security.

\section{ABSTRACT}

What does security look like when it is deployed against rather than by the state? Focusing on the 2011 revolution in Yemen, this essay hints at a number of ways in which the revolutionaries sought to outwit the machinations of state securitization by taking security into their own hands. [Yemen; security; revolution; trust]

\section{REFERENCES}

Allan, Diana

2020 "The Long Turning: A Palestinian Refugee in Belgium." Cultural Anthropology 35, no. 2: 225-30. https://doi.org/10.14506/ca35.2.05.

Burke, Edmund

2003 Reflections on the Revolution in France. New Haven, Conn.: Yale University Press. Originally published in 1790 .

C.A.S.E. Collective

2006 "Critical Approaches to Security in Europe: A Networked Manifesto." Security Dialogue 37, no. 4: 443-87. https://doi.org/10.1177\%2F0967010606073085.

El Dardiry, Giulia, and Sami Hermez

2020 "Critical Security and Anthropology from the Middle East." Cultural Anthropology 35, no. 2: 197-203. https://doi.org/10.14506/ca35.2.01.

Holbraad, Martin, and Morten Axel Pedersen

2012 "Revolutionary Securitization: An Anthropological Extension of Securitization Theory." International Theory 4, no. 2: 165-97.

Li, Darryl

2020 “The Spy Who Came In from the South.” Cultural Anthropology 35, no. 2: 231-36.

Rubaii, Kali https://doi.org/10.14506/ca35.2.06.

2020 "Trust without Confidence: Moving Medicine with Dirty Hands." Cultural Anthropology 35, no. 2: 211-17. https://doi.org/10.14506/ca35.2.03. 